\title{
Ikke for lite, ikke for mye
}

Det er sol og sommer. Men får befolkningen nok vitaminer gjennom naturlige vitaminkilder? Dette spørsmålet har vært stilt mange ganger gjennom tidene, også i Tidsskriftet nr. 18/1938. I en artikkel (Tidsskr Nor Lægeforen 1938; 58: 1062-84) gjennomgås vitamin for vitamin med dets kilder og mengdeangivelser, mye testet ved dyreforsøk.

\section{Vitamininnholdet i friske og hermetiske næringsmidler.}

Av Gulbrand Lunde, Stavanger.
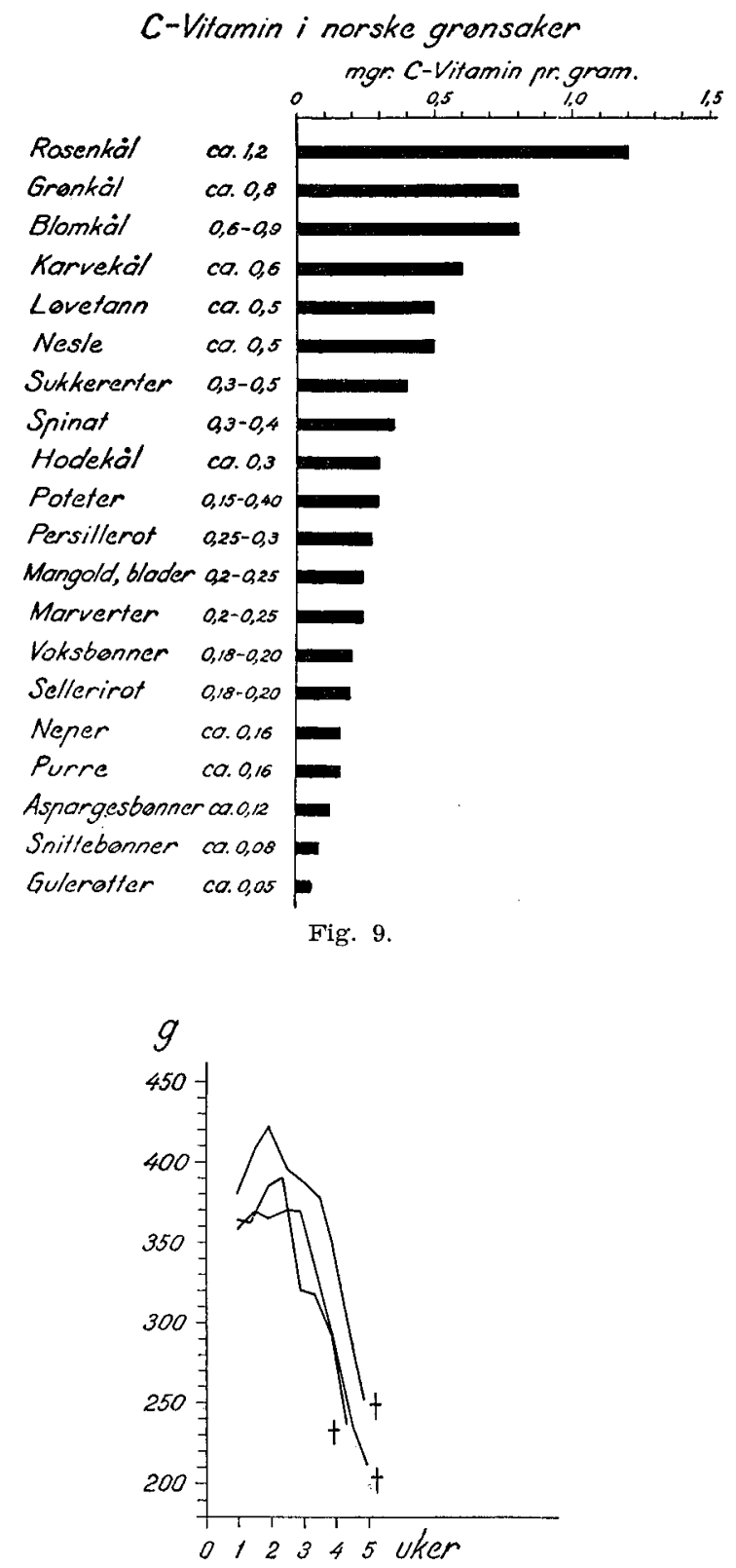

4. Vekstkurver for marsvin fôret med vitamin C-fri kost. Negative kontrolldyr. 